\title{
Effect of histamine on proliferation of normal human adult lung fibroblasts
}

\author{
MANEL JORDANA, A DEAN BEFUS, MICHAEL T NEWHOUSE, \\ JOHN BIENENSTOCK, JACK GAULDIE
}

From the Departments of Pathology and Medicine, McMaster University, and St Joseph's Hospital, Hamilton, Ontario; and the Department of Microbiology and Infectious Disease, University of Calgary, Calgary, Alberta, Canada

ABSTRACT Fibrotic lung tissue shows increased connective tissue deposition and fibroblast proliferation and in addition a substantial increase in mast cell numbers in and around the fibrotic? area. To elucidate the question of whether products of mast cells affect the proliferative behaviour of structural cells in the lung and thereby contribute to fibrogenesis, the effect of histamine, a prominent mast cell derived mediator, on the in vitro proliferation of primary cultures of normal adult human lung fibroblasts was studied. Histamine enhanced fibroblast proliferation in a dose dependentio manner, with an optimum effect at a physiological concentration of $10^{-7} \mathrm{~mol} / 1$. This effect occurred when cells were exposed to histamine at restricted times during cell growth and was shown to dependo in part on the stage of the cell cycle reached by the fibroblasts. The histamine induced proliferations was mediated through an $\mathrm{H}_{2}$ histamine receptor on the fibroblast, being inhibited by cimetidine, an $\mathrm{H}_{20}$ antagonist, and not by pyrilamine maleate, an antagonist of the $\mathrm{H}_{1}$ receptor. Mast cell products such as histamine may interact with and promote the increased fibroblast proliferation found in pulmonary fibrosis.

\section{Introduction}

Pulmonary fibrosis is a disease characterised by the synthesis and secretion of increased connective tissue components such as collagen and fibronectin within the lung structures. ${ }^{2}$ Increased collagen deposition may be the result of increased fibroblast proliferation, increased collagen output per cell, or both. Thus the factors that modulate fibroblast behaviour need to be understood if we are to unravel the pathogenetic mechanisms underlying pulmonary fibrosis and explore new approaches to treatment. The interstitial lung fibroblast may respond with increased proliferation or increased collagen synthesis or both to signals from alveolar macrophages ${ }^{34}$ and lymphocytes. ${ }^{56}$ In addition, evidence from human studies and from our own work with an experimental model of lung fibrosis $^{7-9}$ suggests that mast cells may have a role in the pathogenesis of pulmonary fibrosis. Does then histamine, a major mast cell product, ${ }^{10}$ affect the

Address for reprint requests: Dr Jack Gauldie, Department of Pathology, McMaster University Medical Centre, 1200 Main Street West, Hamilton, Ontario, Canada L8N $3 Z 5$.

Accepted 14 April 1988 proliferative pattern of lung fibroblasts? To answer. this question we first established several primary celf lines of fibroblasts from human adult normal lungs and investigated the direct effect of histamine and histamine antagonists on in vitro fibroblast prolifera tion.

\section{Methods}

FIBROBLAST CELL LINES

Fibroblast cultures were established from histo logically normal areas of lung specimens obtained from patients undergoing surgical resection. Briefly lung specimens were chopped into pieces of less than $1 \mathrm{~mm}^{3}$ and washed once with phosphate bufferedw saline (PBS) and twice with regular growth mediun (RGM) consisting of $10 \%$ fetal bovine serum (FBS) ife Dulbecco's modified Eagle medium (Grand Island Biological Co, Grand Island, New York) with added ${ }^{+}$ antibiotics (penicillin $100 \mathrm{U} / \mathrm{ml}$, streptomycin $100 \mu \mathrm{g} / \overline{0}$ $\mathrm{ml}$, and amphotericin $25 \mu \mathrm{g} / \mathrm{ml}$ ). Three pieces of tissue were then plated in each $60 \mathrm{~mm}$ dish (Corning Glass? Works, Corning, New York) and covered with a slide@ stuck to the dish with sterile soft paraffin. Five millilitres of RGM were added and the tissue was 
incubated at $37^{\circ} \mathrm{C}$ in $5 \%$ carbon dioxide. The medium was changed twice weekly. When the bottom of the dish was coated with a layer of fibroblasts at near confluency, usually five to six weeks later, the pieces of tissue were removed and the cells trypsinised for 10 minutes, resuspended in $R G M$, and replated in $100 \mathrm{~mm}$ tissue culture dishes with $10 \mathrm{ml}$ of RGM. Subsequently the cells were split 1:2 at confluency, usually weekly. Fibroblast aliquots at each passage were frozen and stored in liquid nitrogen. In the experiments we describe below we have always used cells at a passage earlier than the tenth.

In vitro growth characteristics of normal human adult lung fibroblasts

Cell counts Fibroblasts from confluent dishes were trypsinised and resuspended in RGM. Cell viability was assessed by trypan blue exclusion. Viability was $95 \%$ or greater in all experiments. In $35 \mathrm{~mm}$ culture dishes $7 \times 10^{5}$ cells were seeded in $5 \mathrm{ml}$ of RGM $\left(6.6 \times 10^{4}\right.$ cells $\left./ \mathrm{cm}^{2}\right)$ and incubated from 12 to 96 hours at $37^{\circ} \mathrm{C}$ in $5 \%$ carbon dioxide. After various incubation periods the medium was removed and the cells trypsinsed, resuspended in PBS, and immediately counted with the aid of a Coulter Counter (Coulter Electronics Inc, St Hialeah, Florida). Two dishes were prepared for studying each data point.

Thymidine incorporation In flat bottomed microtiter wells (96 wells/plate, NUNC InterMed, Copenhagen) $2 \times 10^{4}$ cells were seeded in $100 \mu \mathrm{l} \mathrm{RGM}\left(6.6 \times 10^{4}\right.$ cells $/ \mathrm{cm}^{2}$ ). The cells were incubated from 12 to 96 hours. In all cases $1 \mu \mathrm{Ci}$ of tritiated thymidine $(20 \mathrm{Ci} /$ mmol, NEN) was added to each well during the last 12 hours of the incubation period. Cell viability at this stage was over $90 \%$ on the basis of trypan blue exclusion. The medium was then removed and the cells trypsinised and collected in a cell harvester (MA Bioproducts, Walkersville, Maryland). Tritiated thymidine incorporation was detected by $\beta$ counting. The results, in disintegrations per minute (dpm), are expressed as the means and standard deviations of the results from replicate wells.

Effect of histamine on fibroblast proliferation Figure 1 illustrates the experimental design. In a microtitre plate $2 \times 10^{4}$ cells $/$ well $\left(6.6 \times 10^{4}\right.$ cells $\left./ \mathrm{cm}^{2}\right)$ were seeded in $100 \mu \mathrm{l}$ RGM and incubated for 72 hours. After various intervals the cells were exposed to fresh medium alone or to medium containing histamine (Sigma, St Louis, Missouri) for 12 hour periods and this medium was subsequently replaced by fresh medium for the remainder of the culture. Tritiated thymidine was added for the final 12 hours, cells were harvested at 72 hours, and thymidine incorporation was determined as above. To synchronise fibroblast proliferation and determine the effect of histamine on cell counts, $7 \times 10^{5}$ fibroblasts $\left(7.2 \times 10^{4}\right.$ cells $\left./ \mathrm{cm}^{2}\right)$ were seeded in $35 \mathrm{~mm}$ tissue culture dishes in $2 \mathrm{ml}$ of

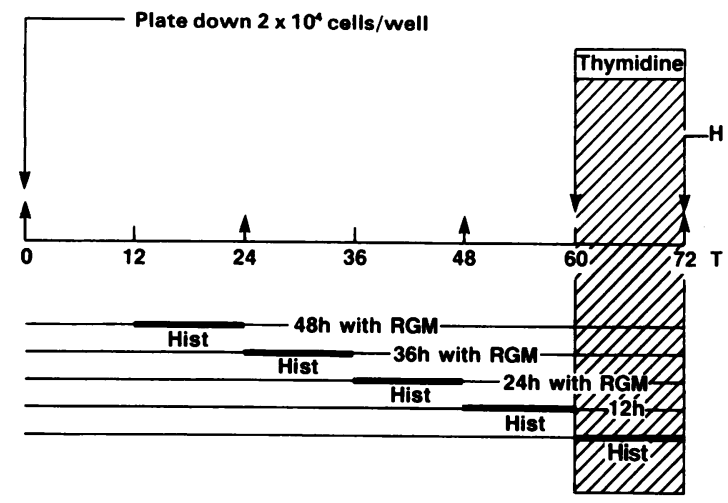

Fig 1 Graphic representation of the experimental protocol for studying the effect of histamine on fibroblast proliferation.

medium containing $0.4 \% \mathrm{FBS}$ and incubated for four days. This medium was replaced by medium containing $10 \%$ FBS to initiate fibroblast proliferation and the cells were incubated for a further 72 hours. As before, cells were exposed for 12 hours to either medium alone or medium containing histamine at different points during the 72 hours of the $10 \%$ FBS incubation period. The medium was removed after 72 hours and the cells were trypsinised and counted.

Effect of histamine antagonists As histamine had a significant effect on fibroblast proliferation when added between 36 and 48 hours we used this protocol to study the effect of histamine receptor antagonists, Cimetidine (Smith, Kline, and French, Philadelphia) at a concentration of $10^{-7} \mathrm{~mol} / \mathrm{l}$ was used as an $\mathrm{H}_{2}$ antagonist and pyrilamine maleate (Sigma, St Louis, Missouri), also at a concentration of $10^{-7} \mathrm{~mol} / \mathrm{l}$, as an $\mathrm{H}_{1}$ antagonist. Fibroblasts were simultaneously exposed to histamine (concentration also $10^{-7} \mathrm{~mol} / \mathrm{l}$ ) and to either one of the antagonists for 12 hours. As before, thymidine was added during the last 12 hours of the 72 hour incubation period and thymidine incorporation determined. Results are expressed as percentage changes from a control culture of fibroblasts with RGM alone. Each numerical point recorded represents the mean of six replicates. Where results are compared for significance, Student's paired $t$ test was used.

Cell cycle assessment Fibroblasts were brought to quiescence by culture in low $(0.4 \%)$ FBS containing medium for four days. Initiation of proliferation and cell cycling was brought about by the replacement of the medium with fresh medium containing $10 \%$ FBS. At various times after initiation of proliferation, cells were removed by trypsinisation, and the DNA content of the nuclei was estimated by the use of an Ortho Spectrum III flow cytometer, ethidium bromide being used to stain the DNA." 


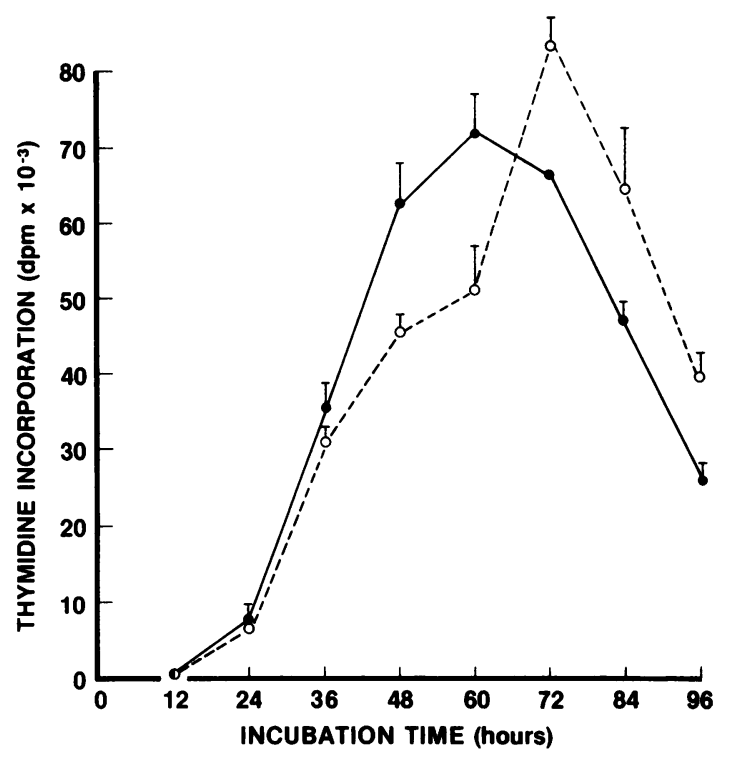

(a)

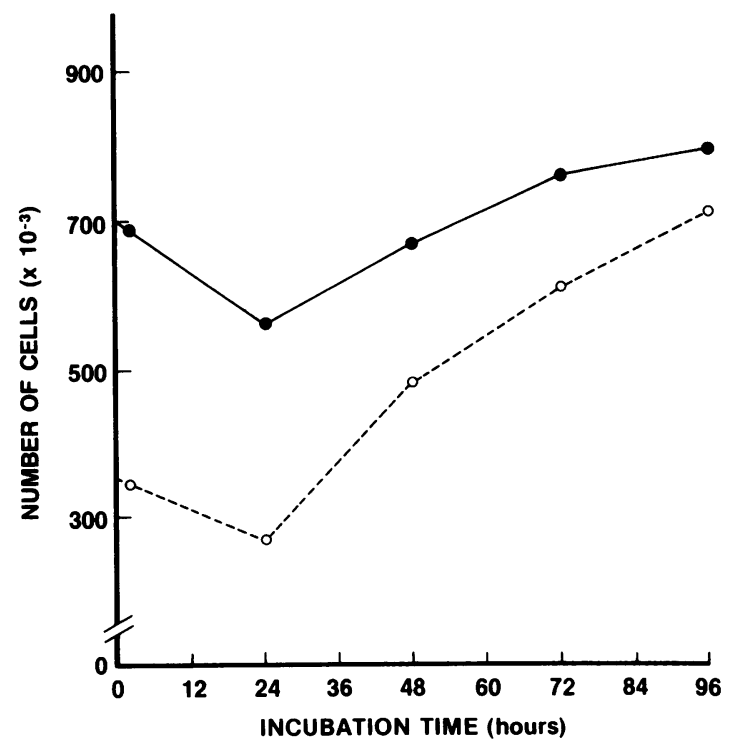

(b)

Fig 2 (a) In vitro growth characteristics of two normal human adult lung fibroblast lines. Data are expressed as the mean tritiated thymidine incorporation in dpm of the two lines, each data point for each cell line being the mean of 12 replicates. $\bigcirc \longrightarrow 03.3 \times 10^{4}$ cells $/ \mathrm{cm}^{2} ; \square-6.6 \times 10^{4}$ cells $/ \mathrm{cm}^{2}$. (b) In vitro growth characteristics of a normal human adult lung fibroblast line. Data are expressed as the mean cell count of two separate samples per time point. $\bigcirc-03.6 \times 10^{4} \mathrm{cells} / \mathrm{cm}^{2} ; \bullet-7.2 \times 10^{4} \mathrm{cells} / \mathrm{cm}^{2}$.

\section{Results}

Figure $2 a$ shows the in vitro growth behaviour of $\stackrel{\bar{F}}{+}$ normal adult human lung fibroblasts with cells seeded $\bar{C}$ at two densities. The pattern of thymidine incorpora- $\frac{\bar{O}}{\bar{N}}$ tion was similar with the two cell densities. Peak $\frac{\bar{s}}{\overrightarrow{0}}$ incorporation in cells seeded at $3.3 \times 10^{4}$ cells $/ \mathrm{cm}^{2} \unrhd$

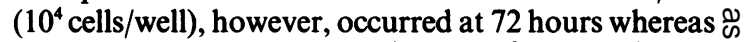
with cells seeded at $6.6 \times 10^{4}$ cells $/ \mathrm{cm}^{2}\left(2 \times 10^{4}\right.$ cells $/ \vec{\circ}$

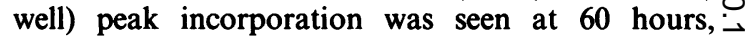
although substantial incorporation had already $\vec{\omega}$ occurred at 48 hours. The same differences were seen $\stackrel{\circ}{2}$ when proliferation (fig $2 b$ ) was evaluated by cell $\vec{x}$ counting. An initial drop in the number of cells $\vec{\omega}$ occurred at 24 hours owing to the loss of non-adherent $-v$ cells removed by the wash after plating. From 24 hours $f$ on, the cell number increased and plateaued between $N$ 72 and 96 hours, particularly in the cells seeded at high 을 density.

When we exposed the cells to histamine at a $\subseteq$ concentration of $10^{-7} \mathrm{~mol} / \mathrm{l}$ using the protocol outlined in figure 1 , there was enhanced proliferation only if $\vec{\oplus}$ histamine was present during specific periods of $\stackrel{\infty}{\infty}$ normal proliferation (fig 3). Histamine had no effect 0 when added during the first 36 hours of the incubation period. In contrast, a significant enhancement of the amount of thymidine incorporation $(+48 \%)$ was seen when histamine was added between 36 and 48 hours.

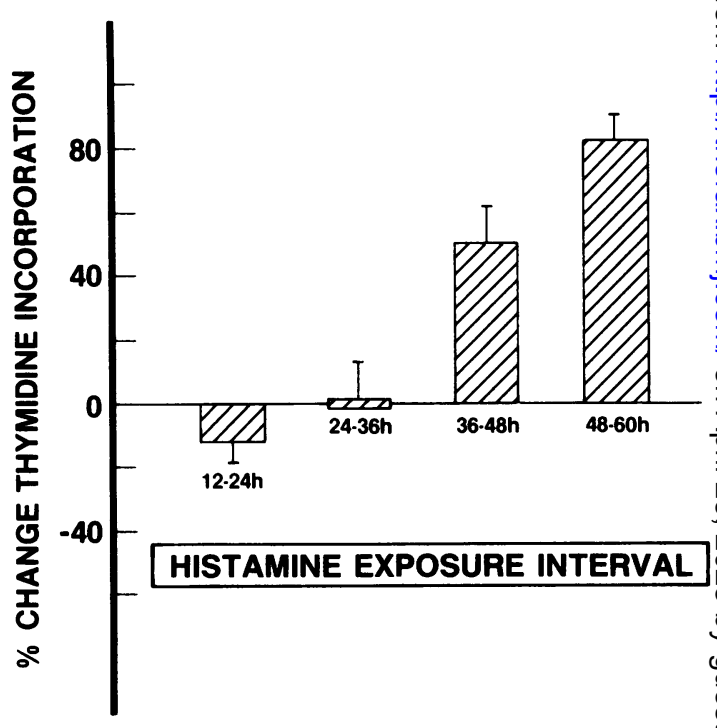

Fig 3 Effect of $10^{-7} \mathrm{M}$ histamine added at different intervals of the cell growth on in vitro fibroblast proliferation at 72 hours, as shown in fig 1. Data are expressed as percentage changes in thymidine incorporation from a control $\frac{\Omega}{(\mathcal{B}}$ culture of fibroblasts. Each data point expresses the mean and standard deviation of six to eight replicates. 


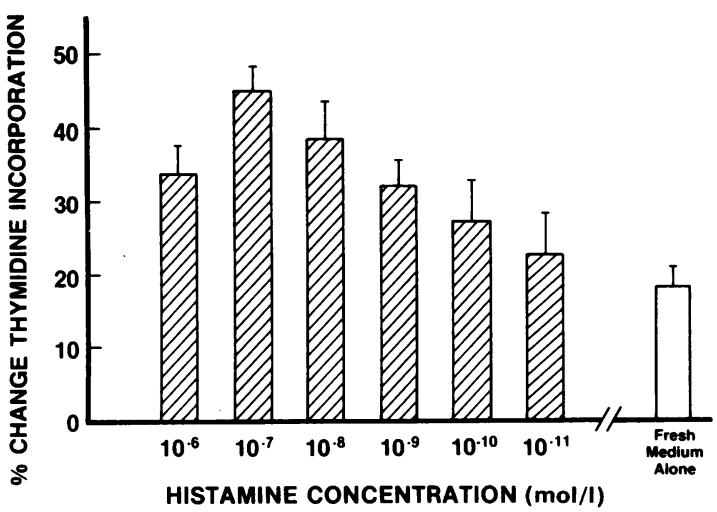

Fig 4 Dose-response relationships of $10^{-6}-10 " \mathrm{M}$ histamine with regard to modulation of normal lung fibroblast proliferation. Histamine was added for a period between 36 and 48 hours during the normal proliferative 96 hour culture. Data are expressed as percentage changes in thymidine incorporation over a normal proliferation response (medium unchanged). $p<0.05$ for $10^{-6}-10^{-9} \mathrm{M}$ histamine by comparison with fresh medium alone. Open bar indicates fresh medium alone and striped bars histamine media.

This enhancement was more striking if histamine was added between 48 and 60 hours $(+84 \%)$.

When histamine at various concentrations (from $10^{-6}$ to $10^{-11} \mathrm{~mol} / \mathrm{l}$ ) was added to cultures of lung fibroblasts between 48 and 60 hours there was a dose dependent increase in proliferation as measured by thymidine incorporation (fig 4). The maximum stimulation ( $45 \%$ above normal incorporation rates) occurred at a concentration of $10^{-7} \mathrm{~mol} / \mathrm{l}$ histamine and was significantly greater than the increased incorporation seen by changing the media alone between 48 and 60 hours.

We confirmed that the tritiated thymidine uptake was due to an increase in cell number and that the increased proliferation was seen in fully synchronous fibroblast cultures. We exposed cells to histamine, using the protocol shown in figure 1, after the cells had been plated at suitable densities, brought to quiescence by culture in low serum conditions, and then induced to proliferate by the addition of $10 \%$ FBS. Significantly higher cell densities were seen with the cell aliquots cultured in this manner and exposed to histamine between 36 and 48 hours ( $57 \%$ increase) and 48 and 60 hours $(70 \%$ increase) than with the cells cultured in medium alone (fig 5).

To determine the period of the cell cycle during which histamine caused stimulation of fibroblast proliferation, cells were caused to proliferate in a synchronous manner as described above. Determination of the DNA content of the nuclei by flow cytometric techniques (fig 6) showed a steady increase in the percentage of cells in $\mathrm{G}_{2}+\mathrm{M}$ phases up to 48 hours $(2.7 \%$ at the outset to $18.7 \%$ at 48 hours-see table).

Exposure of fibroblasts to histamine antagonists alone (cimetidine or pyrilamine) caused no significant modulation of the proliferative response (fig 7). Pyrilamine (at a concentration of $10^{-7} \mathrm{~mol} / \mathrm{l}$ ) did not prevent histamine induced proliferation. Cimetidine $\left(10^{-7} \mathrm{~mol} / \mathrm{l}\right)$ abrogated the histamine enhancement if present at the same time as histamine.

\section{Discussion}

Substantial evidence has accumulated indicating that cytokines released from effector lung cells such as alveolar macrophages and lymphocytes may interact with lung fibroblasts and thereby modulate their functional behaviour. ${ }^{3-6}$ Recently mast cells, which have an abundant mediator armamentarium, have been shown to be substantially increased in fibrotic conditions. Kawanami et al showed that in lungs from patients with various fibrotic disorders there was an increased number of mast cells and these cells appeared to undergo a process of partial chronic degranulation.' We have previously reported a remarkable lung mast cell hyperplasia in a rat model of bleomycin induced pulmonary fibrosis. ${ }^{8}$ In patients with idiopathic pulmonary fibrosis the increase in mast cell numbers correlated with increased histamine concentrations in the bronchoalveolar lavage fluid. ${ }^{9}$ Increased mast cell numbers have also been reported

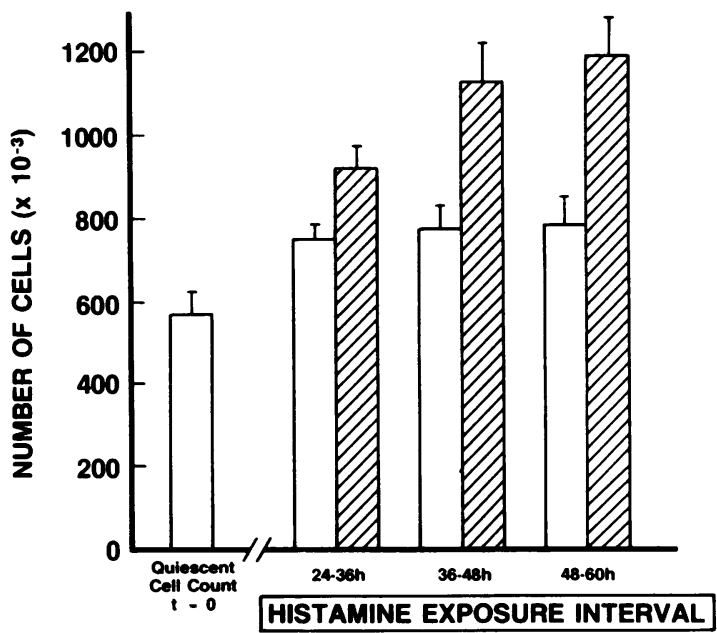

Fig 5 Effect of $10^{-7} \mathrm{M}$ histamine added for 48-60 hours on in vitro proliferating lung fibroblast cell counts. Data are expressed as cell counts at 96 hours with a mean and range of two samples per time point. Open bars indicate fresh medium alone and striped bars histamine media. 
a

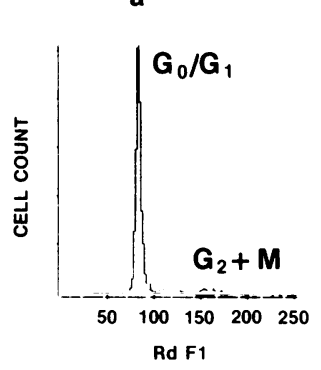

b

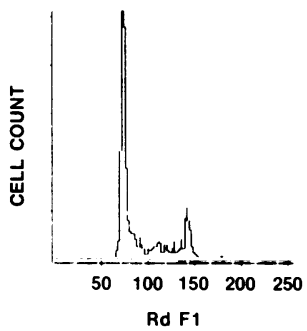

Fig 6 Flow cytometric analysis of DNA content of fibroblast nuclei: cytogram from Ortho flow cytometer. (a) $t=0$; (b) $t=48 \mathrm{~h}$. RdFI-propidium iodine content of nuclei; $\mathrm{Go} / \mathrm{Gl}$-cells in resting quiescent phase; $G 2+M-c e l l s$ entering growth phase.

in experimental models of pulmonary fibrosis induced by asbestos, ${ }^{12}$ silica, ${ }^{13}$ and radiation ${ }^{14}$ and in the skin of patients with scleroderma. ${ }^{15}$

Despite these observations and the hypothesis that mast cells play a part in the pathogenesis of fibrosis, ${ }^{16}$ the actual mechanisms have been little explored and are not understood. There is evidence suggesting that an interaction between mast cells and fibroblasts or their respective products does occur. Atkins et al $^{17}$ reported that human and rat skin fibroblasts were capable of ingesting and degrading mast cell granule heparin proteoglycan. Furthermore, Pilarisetti et al ${ }^{18}$ showed that as a consequence of this process there was

Flow cytometric analysis of DNA content of fibroblast nuclei

\begin{tabular}{|c|c|c|}
\hline \multirow[b]{2}{*}{ Time (h) } & \multicolumn{2}{|c|}{$\%$ cells in phase } \\
\hline & $G_{i}$ & $G_{2}+\mathbf{M}$ \\
\hline $\begin{array}{r}0 \\
12 \\
24 \\
36 \\
48\end{array}$ & $\begin{array}{l}96 \cdot 2 \\
95 \cdot 7 \\
87 \cdot 5 \\
72 \cdot 4 \\
64 \cdot 3\end{array}$ & $\begin{array}{r}2.7 \\
2.8 \\
2.9 \\
12.2 \\
18.7\end{array}$ \\
\hline
\end{tabular}

a functional alteration of fibroblast behaviour as assessed by collagenase production. Franzen ${ }^{19}$ showed $\overrightarrow{\times}$ that histamine at a concentration of about $10^{-10} \mathrm{~mol} / 1 \stackrel{\mathrm{\omega}}{\mathrm{\omega}}$ induced substantial mitogenesis of guinea pig mesen- $-v$ tery fibroblast like cells and that the same occurred in organ cultured rat mesentery after mast cell degran- $N$ ulation had been elicited by the intravenous adminis-음 tration of compound $48 / 80$. As a result of these studies we investigated the direct effect of histamine, an abundant mast cell product, ${ }^{10}$ on the proliferative in vitro behaviour of primary cultures of human adult $\vec{\oplus}$ lung fibroblasts.

In view of the documented heterogeneity of fibroblasts, which differ according to the site and species from which they are derived, ${ }^{2021}$ we first established several primary human adult lung® fibroblast lines. The outgrowth from lung explants yields a virtually pure but heterogeneous population $\stackrel{2}{\rightarrow}$ of normal diploid fibroblasts after two or three음 passages. All the cells used in the experiments reported here had the structural characteristics of fibroblasts,

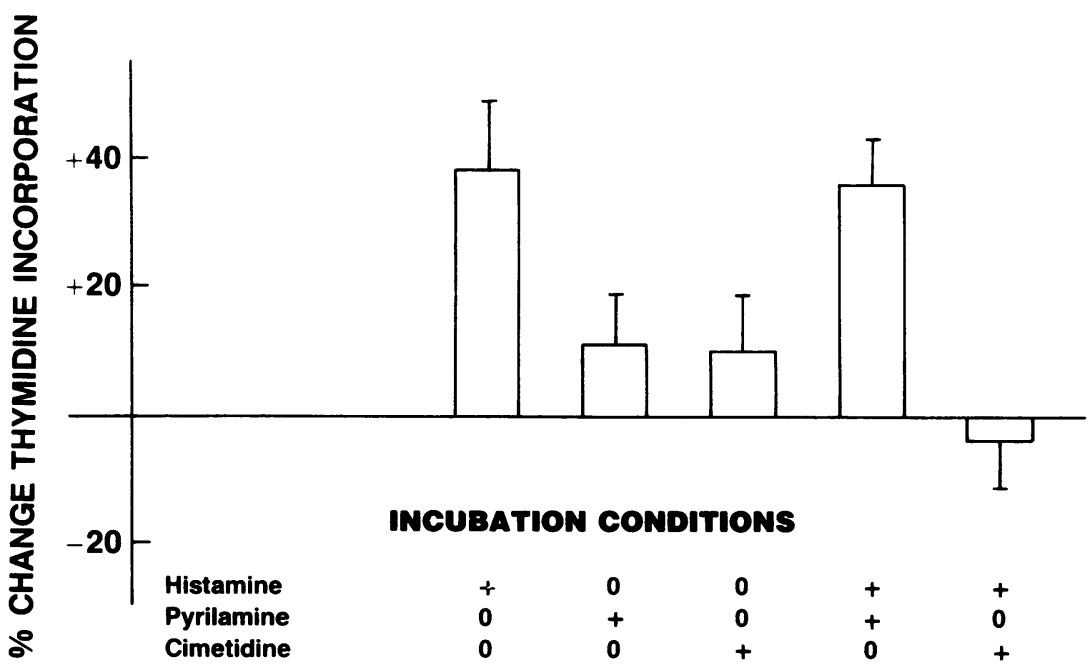

Fig 7 Effect of histamine antagonists on histamine induction of in vitro lung fibroblast proliferation. Histamine or histamine plus the antagonists pyrilamine and cimetidine (all $10^{7} \mathrm{M}$ ) were added to proliferating lung fibroblasts for a period between 48 and 60 hours and the cells harvested at 96 hours. Data are expressed as in figure 5. 
expressed collagen specific messenger RNA, ${ }^{30}$ and had a normal karyotype (data not shown).

Histamine at biologically relevant doses increased thymidine incorporation by fibroblasts as well as increasing cell numbers when added between 48 and 60 hours, and to a lesser extent between 36 and 48 hours, during the total 72 hours' incubation period (figs 3-5). The molecular basis of the effect of histamine on fibroblast proliferation remains unclear, though some insight may be obtained by examining the conditions of the experimental assay we used. Cells were kept throughout the assay in $10 \%$ fetal calf serum, which contains several competence and growth factors. The progressive increase of cells in the $\mathrm{G}_{2}-\mathbf{M}$ phase during the incubation period (table and fig 6) is likely to be due to the presence of these factors. In our experimental protocol we seeded the cells at a high density, which in itself limits cell proliferation as fibroblasts are subject to density inhibition pressures-as illustrated in figure 6, which shows how the addition of fresh medium resulted in only a slight growth stimulation. We used these particular conditions because mast cell mediators are known to increase proliferation, as assessed by thymidine incorporation, cell counting, and the labelling index of dense cultures of 3T3 and fetal lung fibroblasts under maximum "serum stimulation," 22 and because histamine has been shown to enhance proliferation of confluent skin fibroblast monolayers. $^{29}$ When we examined the effect of histamine on either sparse or starved cultures of fibroblasts we saw little or no effect (data not shown). Our results also showed that the histamine induced effect on fibroblast proliferation could be entirely abrogated by concurrently exposing fibroblasts to an $\mathrm{H}_{2}$ but not to an $\mathrm{H}_{\text {! }}$ receptor antagonist. This is in agreement with the observation by Norrby ${ }^{25}$ that intraperitoneal administration of an $\mathrm{H}_{2}$ receptor antagonist fully suppressed the proliferation of rat mesenteric connective tissue cells after apparent stimulation by mast cell degranulation. Together our results suggest that, under specific experimental conditions such as high cell density and growth factor availability that are likely to resemble those occurring in vivo in pulmonary fibrosis, fibroblasts are responsive to histamine, and that this response appears to be related to the restrictive expression of an $\mathrm{H}_{2}$ receptor. There is evidence that the gene expression of some cytoskeletal and surface proteins depends on certain phases of the cell cycle, or it may be affected by factors such as cell shape and cell contact. ${ }^{23}{ }^{24}$ The $\mathrm{H}_{2}$ mediated modulation of cell function documented here is consistent with the broad immunomodulatory effects that histamine shows through interaction with the $\mathrm{H}_{2}$ receptor. ${ }^{26}$

These data showing that histamine directly enhances in vitro fibroblast proliferation may have impor- tant implications for our understanding of the pathogenesis of pulmonary fibrosis. The development of pulmonary fibrosis is the result of an integrated complex interaction between different cells, ${ }^{16}$ the monocyte macrophage being an important cell in this network. This cell, which has histamine $\mathrm{H}_{2}$ receptors, ${ }^{28}$ can release a molecule that enhances histamine release from dispersed human lung mast cells and from peripheral blood basophils. ${ }^{27}$ Mast cell hyperplasia occurs in several experimental models of pulmonary fibrosis as well as in human lung fibrosis and it is of such a degree and of such duration that it may be the major cell type most persistently increased. As the alveolar macrophage and the mast cell interact and also modulate fibroblast proliferation directly, a greater understanding of these interactions should provide insight into the pathogenesis of pulmonary fibrosis.

We gratefully acknowledge the technical support of $\mathrm{G}$ Jordana, J A Schroeder, and $M$ Kardish and the secretarial assistance of $J$ Hickey and $J$ Butera. We are indebted to Drs J E M Young and W Bennett for kindly supplying the surgical specimens. This work was supported in part by the Medical Research Council of Canada and the Council for Tobacco Research Inc of the United States. MJ was a fellow of the Canadian Lung Association and is currently a fellow of the US Parker B Francis Foundation.

\section{References}

1 Madri JA, Furthmayr H. Collagen polymorphism in the lung: an immunochemical study of pulmonary fibrosis. Hum Pathol 1980;11:353-66.

2 Bradley KH, Kawanami O, Ferrans VJ, Crystal RG. The fibroblast of human lung alveolar structures: a differentiated cell with a major role in lung structure and function. Methods Cell Biol 1980;21A:37-64.

3 Bitterman PB, Rennard SI, Hunninghake GW, Crystal RG. Human alveolar macrophage growth factor for fibroblasts: regulation and partial characterization. J Clin Invest 1982;70:806-22.

4 Jordana M, Newhouse MT, Gauldie J. Alveolar macrophage/peripheral blood monocyte-derived factor modulate proliferation of primary lines of human adult lung fibroblasts. J Leuk Biol 1987; 42:51-60.

5 Postlethwaite AE, Smith GN, Mainardi CL, Seyer JM, Kang AH. Lymphocyte modulation of fibroblast function in vitro: stimulation and inhibition of collagen production by different effector molecules. J Immunol 1984;132:2470-7.

6 Wahl SM, Wahl LM, McCarthy JB. Lymphocyte mediated activation of fibroblast proliferation and collagen production. J Immunol 1978;121:942.

7 Kawanami O, Ferrans VJ, Fulmer JD, Crystal RG. Ultrastructure of pulmonary mast cells in patients with fibrotic lung disorders. Lab Invest 1979;40:717-34.

8 Goto F, Befus D, Low R, Bienenstock J. Mast cell 
heterogeneity and hyperplasia in bleomycin-induced pulmonary fibrosis of rats. Am Rev Respir Dis 1984;130:797-802.

9 Haslam PL, Cromwell O, Dewar A, Turner-Warwick M. Evidence of increased histamine levels in lung lavage fluids from patients with cryptogenic fibrosing alveolitis. Clin Exp Immunol 1981;44:587-93.

10 Beaven MA. Histamine: its role in physiological and pathological processes. Monogr Allergy 1978;12:1-113.

11 Vindelov LL, Christensen IJ, Nissen NI. A detergenttrypsin method for the preparation of nuclei for flow cytometric DNA analysis. Cytometry 1983;4:323-7.

12 Wagner MMF, Edwards RE, Moncriell CB, Wagner JC. Mast cells and inhalation of asbestos in rats. Thorax 1984;39:539-44.

13 Religa Z, Maslinski CZ. Histamine metabolism in experimental silicosis. II. In vivo experiments in guinea pigs. Life Sci (II) 1971;10:257-71.

14 Watanabe S, Watanabe K, Ohishi T, Aiba M, Kageyama $K$. Mast cells in the rat alveolar septa undergoing fibrosis after ionising radiation. Lab Invest 1974;31:555-67.

15 Hawkins RA, Claman HN, Clark RAF, Steigerwald JC. Increased dermal mast cell populations in progressive systemic sclerosis: a link in chronic fibrosis? Ann Intern Med 1985;102:182-6.

16 Claman HN. Mast cells, T cells and abnormal fibrosis. Immunol Today 1985;6:192-5.

17 Atkins FM, Metcalfe DD. Degradation of the heparin matrix of mast cell granules by cultured fibroblasts. $J$ Immunol 1983;131:1420-5.

18 Pilarisetti V, Subba Rao, Friedman MM, Atkins FM, Metcalfe DD. Phagocytosis of mast cell granules by cultured fibroblasts. J Immunol 1982;130:341-9.

19 Franzen L, Norrby K. Local mitogenic effect of tissue mast cell secretion. Cell Tissue Kinet 1980;13:635-42.

20 Schneider EL, Mitsui Y, Au KS, Shorr SS. Tissue specific differences in cultured human diploid fibroblasts. $\operatorname{Exp}$ Cell Res 1977;108:1-6.

21 Castor CW, Prince RK, Dorstewitz EL. Characteristics of human fibroblasts cultivated in vitro from differentC anatomical sites. Lab Invest 1962;11:703-13.

22 Norrby K. Effect of heparin, histamine and serotonin on $\frac{\bar{s}}{\vec{D}}$ the density-dependent inhibition of replication in two fibroblastic cell lines. Virchows Arch B Cell Pathobs 1973;15:75-93.

23 Ungar F, Geiger B, Ben-Ze'ev. Cell contact- and shape- $\vec{\circ}$ dependent regulation of vinculin synthesis in cultured $\square$ fibroblasts. Nature 1986;319:787-91.

24 Hynes RO, Bye JM. Density and cell cycle dependence of cell surface proteins in hamster fibroblasts. Celk 1974;11:113-20

25 Norrby K. Mast cell histamine, a local mitogen acting H2-receptors in nearby tissue cells. Virchows Arch Ber Cell Pathol 1980;34:13-20.

26 Beer DJ, Rocklin RE. Histamine-induced suppressor cello activity. J Allergy Clin Immunol 1984;73:439-52.

27 Schulman ES, Liu MC, Proud D, MacGlashan DW Lichstenstein LM, Plaut M. Human lung macrophage induce histamine release from basophils and mast cells Am Rev Respir Dis 1985;131:230-5.

28 Gespach C, Courillon-Mallet A, Lauray JM, Cost $\mathrm{H}_{2}^{\infty}$ Abita J-P. Histamine $\mathrm{H}_{2}$ receptor activity and histamine metabolism in human U-937 monocyte-like cells and human peripheral monocytes. Agents Actions 1986;18:78-84.

29 Russell JD, Russell SB, Trupin KM. The effect of histamine on the growth of cultured fibroblasts isolated from normal and keloid tissue. $J$ Cell Physio 1977;93:389-94.

30 McSharry C, Jordana M, Harnish D, Kelly J, et al Procollagen gene expression by primary fibroblast line derived from control and fibrotic lung tissue in humans [Abstract]. Am Rev Respir Dis 1987;135:A306. 